Article

\title{
Eating Serial: Beatrice Lindsay, Vegetarianism, and the Tactics of Everyday Life in the Late Nineteenth Century
}

\author{
Liam Young \\ Department of English and Film, University of Alberta, Edmonton, AB T6G 2E5, Canada; \\ E-Mail: lwyoung@ualberta.ca; Tel.:+1-780-200-0126 \\ Academic Editors: Chloe Taylor and Kelly Struthers-Montford
}

Received: 13 November 2014 / Accepted: 13 January 2015 / Published: 22 January 2015

\begin{abstract}
This paper derives from research I conducted in the archives of the Vegetarian Society, in Manchester, in October 2011 on the figure of Beatrice Lindsay, a graduate from Girton College, Cambridge, who, in 1885, became the first female editor of the Society's journal, the Dietetic Reformer and Vegetarian Messenger. In addition to her position as editor, Lindsay contributed a monthly column on "New Foods" in which she displayed her fluency with scientific terminology not simply to advocate the vegetarian diet, but to make the diet practicable for readers. I argue that her column uses the serial form of the periodical, which presents novel content within a regular structure, to shape inchoate vegetarianism: she gradually constituted the emerging diets, habits, and bodies of vegetarians by, each month, introducing readers to novel content ("new foods") within a recurrent form.
\end{abstract}

Keywords: vegetarianism; periodical studies; Beatrice Lindsay; food choices; social change; Foucault; the ethics of eating

The theory of Vegetarianism has been mostly advocated by gentlemen; the practice of it must be undertaken by the ladies. We need an army of lady speakers and teachers of plain cookery.

—Beatrice Lindsay, speaking at the Annual Meeting of the Vegetarian Society, 1891 Moreover, alimentary habits constitute a domain where tradition and innovation matter equally, where past and present are mixed to serve the needs of the hour, to furnish the joy of the moment, and to suit the circumstance. With their high degree of ritualization and 
their strong affective investment, culinary activities are for many women of all ages a place of happiness, pleasure, and discovery.

—Luce Giard, The Practice of Everyday Life Volume 2

\section{Introduction}

In July 1883, the official organ of the Vegetarian Society, the Dietetic Reformer and Vegetarian Messenger, announced that one of its subscribers, Beatrice Lindsay, a student at Girton College, Cambridge, had recently passed her examinations in Natural Science with honours [1] (p. 200). Two years later, in 1885, the journal appointed Lindsay as its editor, making her the first female editor in its history [2] (p. 256). Other than these details and a handful of other facts that I have gleaned from the pages of the Vegetarian Messenger, I know little about the life of "Miss Beatrice Lindsay." ${ }^{1}$ She does not figure prominently in the academic studies of the movements she supported-vegetarianism, feminism, and animal rights - possibly because her tactics, particularly in the case of vegetarianism, targeted everyday routines rather than political or legal reform. As a "Girton Girl" and the editor of a humanitarian organ, Lindsay was both a product and agent of social change. Her advanced education and employment outside of the home align her with the characteristics of the emerging "New Woman”, while her work in press provides us with a nodal point to examine the late-Victorian intersection of vegetarianism and feminism. Lindsay contributed to scientific journals-her meticulously illustrated paper “On the Avian Sternum” for the Zoological Society established her as an oft-cited authority on the subject [3] — and in the 1890s she embarked on a career in popular science: in 1895 she published a comprehensive Introduction to the Study of Zoology, which she intended both as a guide to the amateur and as lesson in humane science [4], and in 1902 she issued The Story of Animal Life as part of George Newness's series, the Library of Useful Stories [5]. Her literary output for the Vegetarian Society_-book reviews, editorials, columns on cookery, and, importantly, correspondence with contemporary feminist journals - falls within the category of ephemera, but, as I want to contend, this material is significant precisely for its ephemerality and engagement with the quotidian. In her monthly interactions with readers, she blended New Journalistic intimacy with scientific terminology, at once challenging the masculine ownership of science and enabling her female readers to transform daily routines into "a place of happiness, pleasure, and discovery" [6] (p. 151), as my epigraph from Luce Giard puts it. Vegetarians and animal rights activists from the nineteenth century are often heralded for being ahead of their times-indeed, these are precisely the terms that Peter Singer, the contemporary philosopher of ethics, uses to introduce the 1980 reissue of Henry Salt's Animals' Rights Considered in Relation to Social Progress [7] (p. x). By contrast, I suggest that Lindsay's imbrication in her times and in the "periodical time” [8] (p. 183) of Victorian print culture allowed her to respond to the needs of her readers, and to popularize the eccentric practice of vegetarianism. Serialization in the nineteenth century (the publication of novels and essays in ongoing installments or part-issues) developed into a widespread strategy by which editors and publishers cultivated "ritualized patterns of consumption” [9] (p. 41) among readers. Beatrice Lindsay, I argue, deployed the economy of

1 I am grateful to Susan Furmage, the current Enquires and Advocacy Officer of the Vegetarian Society, for her help narrowing down the dates of Lindsay’s editorship, which, as far as we could determine, ended by 1895. 
serialization as a way of guiding fledgling vegetarians toward the habituation of the practice. The cultural rhythms of serialization, in part-issues and in periodicals, organized the way in which texts were marketed and consumed [10] (p. 31), but, as I will explain, seriality also offered a way of conducting individuals on the path toward vegetarianism. Lindsay's contributions to the Dietetic Reformer and Vegetarian Messenger demonstrate that this advocacy journal fulfilled a much wider social function than propaganda. Page by page, issue by issue, and volume by volume, participatory vegetarian media sustained a conversation on re-imagining and shaping alternative tastes, collective identities, and cultural practices in late-Victorian England.

When Lindsay took the helm "as Editor in the service of the Vegetarian Society" [2] (p. 256) in the 1880s, the Society's journal was known as the Dietetic Reformer and Vegetarian Messenger, but during her tenure it returned to its original title of the Vegetarian Messenger, which it first adopted in 1849. By Lindsay's time, the Vegetarian Messenger had developed from a plain newssheet into a wide-ranging miscellany that conveyed a variety of vegetarian messages to different vegetarian and non-vegetarian audiences, attempting to appeal to readers both inside and outside of the vegetarian fold. The distinctive characteristics of the periodical as a genre, particularly its seriality and miscellaneity [9] (p. 30), allowed the journal to draw together heterogeneous disciplines and discourses within its pages, spatially juxtaposing, for example, nutritional science, moral philosophy, and domestic cookery. During Lindsay's reign it continued to advocate abstinence from flesh on moral grounds and to publish news items of interest solely to its vegetarian subscribers, but it also shifted its tactics and began to target niche audiences, publishing a Ladies’ Page (“Chit Chat for Ladies”), a supplementary children's magazine (The Daisy Basket), and a Christmas Annual (Almonds and Raisins, which Lindsay also edited). "Chit-Chat for Ladies," as its name implies, participated in the "chatty" genre of the New Journalism, but its conversational dialogues on cookery and social entertaining also sought to preserve, within an increasingly anonymous urban environment, the socially embedded, affective, and oral transmission of culinary techniques, recipes, and experiences. The commercialization of journalism in 1880s and 1890s, with its appeal to domestic issues and entertainment rather than parliamentary debate, represented for many commentators a decline in the standards of serious journalism [11] (p. 130); [12] (p. 14), but, as I want to suggest, “Chit Chat for Ladies” and similar features in the Dietetic Reformer and Vegetarian Messenger challenged the distinction between rational discussion and frivolous chitchat. Incorporating elements of the New Journalism and women's magazines, the journal under Lindsay blurred the distinction between a propaganda organ and the commercial press, and it imbued the cultivation of an alternative consumer identity with political significance. Lindsay's investigation and explication of vegetarian cookery made a tactical intervention into late-Victorian biopolitics - an intervention that had implications for both nonhuman and human animals. At a time when the trade in live cattle was developing into a global industry [13] (pp. 1-4), when medical science was vivisecting animals [14] (pp. 128-143); [15] (pp. 277-281), and when "therapeutic commodities" were colonizing the female body [16,17], Lindsay took the body—its health, appetites, and physiological needs - as a site of resistance to the encroaching control and commodification of life. By instructing readers on how to practice food reform in the home, she and other vegetarian advocates, such as Dr Anna Kingsford, Dr Frances Hoggan, and Chandos Leigh Hunt Wallace, gave their readers the tools to resist the pastoral power and "modern priestcraft" of medical men. 
If one purpose of this article is to examine the overlapping commitments of late-nineteenth-century vegetarianism and feminism, I also want unfold an argument on the importance of print culture in effecting the ritualization and incorporation of vegetarian commodities within daily life. These two aspects are complementary: new vegetarian foods were a key ingredient in the debates and interpretations of the new woman in the periodical press. While cultural anthropologists have documented the importance of cooking and eating as social practices of identification, scholars of the periodical press have demonstrated its importance in forging the rhythms of modernity and new political identities [8,12]. Although distant spatially, readers of periodicals are unified temporally through the patterns of serial publishing (weekly numbers, monthly parts, and yearly volumes). My contention is that Beatrice Lindsay, as a contributing editor to a food reform journal, staged her intervention at the intersection of text and taste, intertwining the rhythms of reading and eating in the creation of a vegetarian identity and community. If, as Judith Butler argues, identities are instable, performative, and in constant need of reiteration [18], I want to suggest that the repetitive framework of the periodical press buttressed the emergence of a vegetarian subjectivity. We must remember that, in the nineteenth century, vegetarianism, as a material practice and cultural identity, was still inchoate. Beatrice Lindsay, I suggest, created new vegetarians by inviting them into the process of inventing, producing and practicing vegetarianism, a task for which the serial and participatory genre of the periodical was particularly well suited.

Thus, central to my argument is the claim that we cannot read the development of the vegetarian social movement separate from the medium through it was communicated. The medium was very much the message [19] (p. 23). Rather than read Lindsay's columns and contributions in isolation, I attend to how the form, periodicity, and paratextual advertising of vegetarian journals were all integral to the development of a vegetarian commodity culture and alternative way of life that appealed to and addressed women. The adoption of a vegetarian diet entailed, as the Honourable Mrs Bruce put it, "a radical change in life" [20] (p. 88) that disrupted domestic economy and alienated one from the conventions of society. I focus on the way the form of the periodical worked to familiarize this unfamiliar change in life. The periodical's spatial juxtapositions and its characteristic negotiation between novelty and familiarity, difference and repetition [9] informed Lindsay's presentation of vegetarian practice and helped embed it within everyday life. The dynamics of serial publication allowed Lindsay and the Vegetarian Messenger to situate the strangeness of consuming foreign foods within a repetitive and recognizable structure, and thereby to mitigate the singular difficulty of being a vegetarian in the Victorian period. Lindsay and her readers made use of the rhythms of the periodical press and an expanding market of global commodities in order to give shape and coherence to an emerging lifestyle of vegetarianism, making it into a habitual, comprehensible, and collective practice.

\section{The Science of Vegetarianism}

Lindsay's term as the editor of the Vegetarian Society appears to have come to a close in $1895 .^{2}$ I have been unable to find a reason for her resignation in the pages of the Vegetarian Messenger, but

2 A review of her Introduction to the Study of Zoology published in the Vegetarian Messenger in 1896 opened by referring to Lindsay as "the former editor this magazine." Again, I would like to thank Susan Furmage for this reference. 
its timing closely corresponds with the publication of her Introduction to the Study of Zoology, and we can perhaps infer that she stepped down from her editorial position to devote herself to a career in science publishing. Even here, however, Lindsay continued to cultivate a vegetarian sensibility by promoting her own interpretation of zoology and evolutionary theory. She emphasized the underlying unity of all life rather than the competition for survival, articulating what she saw as the moral dimensions of evolution. As a Girton educated and trained scientist, Lindsay identified herself with modern evolutionists and scientific professionals, but she also recognized that the practice of science and its instrumental rationality had to change. Zoological research depended on dissection-Lindsay herself conducted studies of avian embryos, and she acknowledged that new students would similarly be eager to learn about the "internal structures of animals" [4] (p. 326) —but she reminded readers of her Introduction "that the dead animal body, whatever its kind, should be regarded with a certain reverence” (p. 327). This reverence was, for Lindsay, an extension of, and not antithetical to, Darwin’s materialist account of life's development. Throughout the nineteenth century, even before Darwin, evolutionary theories were associated with atheism and political radicalism, but "the 1880s marked a turning point in the cultural status of evolution” [21] (p. 305), and discussions of evolution became pervasive in popular print culture, including vegetarian propaganda. Lindsay used the new status of Darwin to guide her readers away from laboratory practices and toward an appreciation of living nonhuman animals. Darwin, she reminded readers, had developed his theory of evolution not in a laboratory, but in the field, watching animal life in its "natural conditions" [4] (p. 326). As she further argued, "[t]he observation and companionship of healthy and happy animals (not shut up in cages) is an everlasting source of fun” (p. 335). Darwin, however, not only provided a model for how to observe animals; his evolutionary theory, which revealed the continuity and kinship of all life, also had implications for the relations between human and nonhuman animals, collapsing the distinction between the human subject and animal object. For Lindsay, ethics and epistemology were inseparable: the revelations of Darwinian evolution demanded a radical reassessment of what it meant to be human, and of how humans treated nonhuman animals, particularly those animals used for food and experimentation. The modern ideas of evolution and development were, she argued, not ends in themselves, but a platform for the realization of a higher and wider science, "a science which will find place for clear and sympathetic understanding of the manifold varying forms under which we recognize the mysterious unity called Life" [4] (p. 340). Lindsay thus took on the role of the popularizer and public educator, addressing herself to the burgeoning late-Victorian readership, but she was not satisfied with simply disseminating scientific ideas to readers. She also wanted to redefine science and shape readers' awareness of themselves in relation to other animals. The popular understanding of science and evolution, Lindsay recognized, was the battleground for carving out an alternative model of natural and social order.

Lindsay began to formulate the relationship between Darwinian science and vegetarianism during her time as editor of the Vegetarian Society. In 1887, she articulated what we might call the stakes of vegetarianism. In two complementary lectures delivered as part of the Manchester Vegetarian Lecture Series - and, indeed, the conventions of series and seriality were integral to her progressive, teleological understanding of evolution and the future of vegetarianism-Lindsay laid out the humane and scientific reasons for her practice of a vegetarian diet. The first lecture, "Vegetarianism and Higher Life,” represented vegetarianism as an elevated and evolved state of consciousness, one that 
recognized "the duty of humanity to animals" [22] (p. 42). The second, "Man Not Carnivorous," defended it from the perspective of anatomy: modern taxonomy classified "the human animal" as a “frugivorous animal” [23] (p. 73). "Man," whether he liked it or not, was a vegetarian. He ate meat not from necessity or from nature, but from habit and custom, and Lindsay argued that it was time for him to return to his "primitive food" (p. 74). These two lectures, morality and science, were complementary: Lindsay represented her "higher" and "wider” concept of moral duty to animals as a direct reflection of, and the only logical response to, the insights of evolutionary theory. The revelation that all life shared the same origin, and that all life forms were mutable and interdependent, required an expansion of the very concept of responsibility and of the frames that, as Judith Butler argues, determine moral recognition [24] (p. 22); [25] (p. 508). Lindsay acknowledged that few "men of science" would themselves draw this conclusion or support vegetarianism's humanitarian principles, but she deployed their work tactically, appropriating it for her own ends. Vegetarians, she claimed, could "use them [the men of science] as a skillful diplomatist uses foreign allies, to strengthen us indirectly by crushing our opponents” [23] (p. 70). Lindsay cited the cultural authority of science, but her citation gave it a new context and meaning; her advocacy of vegetarianism thus developed as citational or "rearticulatory practice," a practice that, as Butler argues, is enabled by the very discourses, norms, and powers that it resists [18] (p. 15). Lindsay strategically used "the men of science" in order to erode male authority, and tear down "the old superstitions" that had "placed man on a pinnacle apart from the rest of the animal world” [23] (p. 70). As Lindsay further argued, "[t]he voice of modern science has unhesitatingly bidden him come down from that pinnacle and take his place with more humility and more becoming dignity among the other animals” [23] (p. 70). Modern science's humbling of the human demanded a transformation of social and economic relations with other animals. As Lindsay asked her audience, "does not a full sense of our relations with the world around us, and of our responsibility to all with whom we come in contact, demand that we should cease to inflict cruelty on animals?” [22] (p. 44, my emphasis). Lindsay identified relationality, which she often called kinship, with ethical responsibility. Adopting the pervasive and popular discourse of evolution, Beatrice Lindsay did not advocate extending legal rights to animals. Rather, she wanted to impress upon readers "our relations” with nonhuman animals. Hence, as I am suggesting, while she saw science as a tool for promoting vegetarianism, she also wanted to transform scientific knowledge, identifying a moral imperative in the study of zoology: "The study of the animal kingdom, as a whole, ought to impress us strongly with a feeling of kinship to our poor relations, the 'lower animals,' as they are called” (p. 334). Lindsay added an "ought” to the scientific study of "what is": the study of animal life should draw us closer to other animals, causing us to feel our kinship with them. For Lindsay, evolutionary inheritance from and "contact" with other forms of life-contact that was undeniable given that all life emerged from the same common source-entailed ethical responsibility.

This, then, was the message and moral imperative that, according to Lindsay and other late nineteenth-century vegetarians, confronted post-Darwinian humans: "man" is not who he thinks he is, and must reconcile what he knows about himself and other animals with how he treats other animals. The obstacle facing nineteenth-century vegetarian advocates, a problem they continue to confront in the twenty-first century, involved integrating the "great lesson" [4] (p. 334) of modern science into the everyday lives of others. The impersonal "voice of science” may have bidden "man” to come down from his pinnacle, but was "man" listening, and was he willing to relinquish his position? Even "the 
men of science," whose textbooks on physiology and anatomy demonstrated that "man" could subsist healthily on a vegetarian diet [23] (pp. 70-73), scoffed at the idea of humane vegetarianism. Vegetarianism could not be proven or refuted on science alone. As Jacques Derrida argues, men do not eat meat for nutritional or scientific reasons, or because animal protein is irreplaceable; rather, they consume animal flesh "because of the image of man it reflects back to [them]" [26] (p. 71).

Lindsay and other female vegetarian advocates became increasingly skeptical that "man," despite the mounting evidence of his imbrication in animal life, would be willing to relinquish the virile, autonomous image of himself. Only women, they argued, could ensure that the practice of vegetarianism became an actuality, but vegetarianism also allowed women to take on leadership positions and re-define themselves. Denied access to political power, women found in the vegetarian movement a field of agency that reconciled traditional gender roles with their new demands for a voice in the public sphere. As Michelle Tusan notes, feminist journals of the 1890s, such as Shafts and the Woman's Herald, often legitimated their interest in political and social issues by presenting it as an extension of domestic duties: the New Woman was the truly womanly woman, not a departure from womanhood [12] (pp. 130-133). The Vegetarian Society, because of its dual emphasis on the domestic and national reform, provided progressive women with a platform to navigate and experiment with new political identities, identities that could still be seen as congruous with traditional feminine attributes. For instance, at the Annual Meeting of the Vegetarian Society in 1893, Mrs. Wokes of Liverpool, who took the platform just before Lindsay, argued that "Vegetarianism was essentially a woman's question" [27] (p. 414). Women were, she claimed, "more easily convinced than the gentlemen" (p. 414), and she "called upon the ladies to take a greater interest in the Vegetarian cause" (p. 414). Women such as Mrs. Wokes appropriated vegetarianism as a woman's cause, a cause capable of being undertaken only by women. The radical feminist and vegetarian, Anna Kingsford, drew an explicit connection between "the agitation for women's rights" and vegetarianism in her first public lecture on "the vegetarian question" [28] (p. 4), while more domestic women, those who may not have been among the vanguard of the women's rights movement, could still perform cookery demonstrations or host tea meetings at their homes. A female vegetarian advocate could be both womanly and political, exercising her domestic knowledge while also participating in debates on the national economy, public health, and animals' rights. What was at stake in discussions of vegetarianism was thus not just the proper or natural diet of humanity, but who a woman could or ought to be. As Mrs Bruce argued in an article on "Vegetarianism in the Household",

women are specially attracted to the idea of an innocent and refined diet. I mean no offence to the opposite sex [...] but I look on the tendency toward mercy and refinement most certainly as a distinctively feminine attribute, one which we should develop with all our soul, and with all our strength; for it is far reaching - a mild but powerful weapon in our hands. [29] (p. 351)

The New Woman, the "truly womanly woman" and the woman of the future, would be a vegetarian, but vegetarianism could itself be a "powerful weapon” to renegotiate gendered identities. Food reform began in the home, as many argued, but it also brought women out of the home and made them essential actors in the public campaign to reform the nation by improving its diet [30] (p. 201). 
Chloe Taylor, in an article on the ethics of eating and animal rights advocacy, suggests that, rather than advance utilitarian and deontological arguments, the contemporary animal liberation movement follow Michael Foucault in reactivating a Greek model of ethics, presenting vegetarianism as an exercise of the self [31]. Lindsay too was critical of a "strictly utilitarian" [22] (p. 43) understanding of duty, and, as I want to suggest, she encouraged other women to adopt everyday vegetarianism by re-conceptualizing it as practice of self-transformation rather than a moral injunction. ${ }^{3}$ Her attempts to frame vegetarianism as an exercise of self-fashioning come across in her re-articulation of the concept of duty; she presented "the duty of humanity to animals" not as a privation or act of self-renunciation, but as an exploration of different and, for her, better pleasures: "Its watchword is not merely 'thou shalt not,' but 'thou shalt'” [22] (p. 43). The foundational Christian law-Thou Shalt Not Kill, which nineteenth-century Christian vegetarians extended to all life-here becomes a permissive invitation. Lindsay told her readers, you shall. That is, she did not discipline her audience, prohibiting the flesh, but instead opened up avenues for self-transformation. Abstinence from flesh was not negative, but productive: it made possible the invention of a new and distinct ethics of self-care, and allowed its practitioners to define and create themselves. For Beatrice Lindsay, reorienting "our position in the universe" allowed vegetarians to "feel the multitudinous relations which bind us to other sentient creatures” [22] (p. 44, my emphasis). As I want to demonstrate, the cultivation of a moral and affective community, a community that feels and tastes the world differently [25], took place in the pages of the feminist and vegetarian presses.

For the Greek citizens of Foucault's History of Sexuality, dietetics was a foundational technique of the self, a practice of civic masculinity and self-government. As he points out, in classical treatises on regimen, "the question of foods [...] was a good deal more important than sexual activity" [27] (p. 114). Dietetics represented the art of government applied to the self, allowing the practitioner to act as the pilot and authoritative guide of his or her own body and conduct: "It was a whole manner of forming oneself as a subject who had the proper, necessary concern for his body” [32] (pp. 138-139). In his history of the modern subject, however, Foucault laments that Christian "pastoral power” assimilated such "techniques of the self" into disciplinary institutions (first religious, then medical, educational, and penal), causing them to lose their "autonomy" [32] (p. 11). Through the technology of the confession, "pastoral power" created the modern concept of the subject as a patient-a passive individual who required the analysis, interpretation and guidance of an authority, but not the active input and work of the individual on him or herself. If, as Foucault and Taylor suggest, resistance to modern forms of "pastoral power" must take on an ethical dimension, offering a critique of the type of individuality imposed upon us [33] (p. 785), it is worth pausing to consider the figure of the pastor,

3 The parallel between Foucauldian ethics of self-care and nineteenth century vegetarianism is not as tenuous as it might seem: nineteenth-century vegetarians returned to the same classical source material as Foucault. The Pythagoreans were, according to Foucault, responsible for the development of dietetics [32], while Pythagoras was, claimed the nineteenth-century vegetarians, the first vegetarian, an individual who abstained from flesh in principle and practice. Howard Williams' The Ethics of Diet, which was first serialized in the Vegetarian Messenger between 1878 and 1883 , begins with entries on Hesiod, Pythagoras, Plato, Plutarch, Pythagoras, and Seneca, classical philosophers who are also touchstones for Foucault. Pythagoras also supplied the Vegetarian Society with its maxim, which it emblazoned on the front cover of its journal: "Fix on that course of life which is most excellent, and custom will render it the most delightful.” 
who serves as the point of departure for Foucault's thinking about governmentality: the pastor, from the Latin, means the feeder. The pastor feeds: he is the shepherd who feeds the flock, or, more specifically, he feeds by directing the sheep to their appropriate food, guiding them to safe pastures [34]. The act of feeding animals thus underpins Foucault's model of governing humans: to feed is to govern. While Foucault adopts the relationship between pastor and flock as a metaphor to explain the art and objectives of government [33,34], I suggest that we read Beatrice Lindsay as a very literal counter-pastoral figure. She refused to be pastored or guided in her daily food choices. Instead, she identified food and feeding as the locus of self-transformation and resistance to governmental powers. She may have adopted modern pastoral discourses and technologies, such as physiology, anatomy, mass media and advertising, but she used them to search out a new way of feeding and caring for the body. More importantly, her daily practice and moral theory undermined the basic premise of pastoring, the feeding and fattening of nonhuman animals for human consumption. Lindsay was the anti-pastor, a pastor against the pastoring of animals: "primitive man," she argued, was once a happy and harmless vegetarian, but he had lost his way through the civilizing process, developing an unnatural taste for Butcher's meat; it was now time to guide him and the wayward masses of industrial England back toward healthier, greener, and more humane pastures.

Lindsay thus reactivated the ancient technique of dietetics as a tactic in animal liberation, but she also inflected it through the lens of evolutionary biology, and redirected it toward her feminist vegetarian ends. For Lindsay, and for other late-Victorian radicals such as Anna Kingsford and Edward Carpenter, opportunities for transforming the ethical and political structure of society accrued from the recognition that "the life of human beings, too, is governed by the same laws as the world of animal life” [4] (p. 64). Recognizing, and indeed, feeling, our embeddedness in, rather than transcendence from, "the world of animal life" made it seem possible to imagine transforming ourselves: evolutionary thought in the nineteenth century historicized life, displacing the static and hierarchical chain of being with a serial and temporal process of succession [35] (p. 254). As Lindsay told her amateur zoologist readers, "evolution is still at work" [4] (p. 63), and as such "[t]he world of the future will contain new and beautiful forms of animal life which we have not seen” (p. 64). What was was not permanent, but subject to change. This mutability applied to human animals as well, and the practice of feeding offered a technique to modify and enhance it: through the practice of vegetarian dietetics, Lindsay and others believed that they could sculpt new bodies and subjectivities, ushering into existence "the man of the future" and of course "the woman of the future" [23] (pp. 76-77). Vegetarianism was both the means toward and objective of evolutionary progress: as Anna Kingsford argued, "We are that which we eat [...] If we feed purely and wisely, we will be pure and wise” [24] (p. 4). Vegetarians were the pastors of themselves, eating their way to moral and physiological salvation. In a post-Darwin world, a biopolitical world, ideological struggle took place not simply at the level of legal and political superstructures, but at the level of the body and biological processes [36] (p. 143). Lindsay, Kingsford, and the Vegetarian Society did not seek to influence the state; rather, they pursued the transformation of themselves and the formation of new identities, attempting to change social relations directly through what they ate rather than through legal or political measures. For Lindsay and Kingsford, political and social reform began with the most basic and fundamental act of subsistence, that is, with the physiological reformation of the body. 
Vegetarianism was supported by science, but Lindsay also gave the ancient practice of dietetics a distinctly nineteenth-century feel by framing it as a scientific experiment conducted on oneself: in a letter to the pioneering feminist newspaper, the Woman's Penny Paper, Lindsay described her conversion to vegetarianism as the result of a long process of self-transformation wrought by practical experimentation:

It is now more than fifteen years since this question first engaged my attention. After several years of experiment, I at last succeeded in making my practice square with my theory, and gave up the use of animal food. There are few steps in life on which one can look back with absolute satisfaction; but this is one of them [37] (p. 67).

Lindsay here appropriates and re-articulates the disciplinary technology of the confession for her humanitarian goals, using self-disclosure to publicize and cultivate a vegetarian subjectivity. She narrates a process not of self-discovery, but of self-constitution, representing her conversion to vegetarianism as the outcome of a long battle within herself. As I am suggesting, her vegetarian narrative constitutes an act of "counter-conduct" [34] (p. 201), in which the self is not revealed but forged through an agonistic contest. Her vegetarian identity was an achievement that she arrived at only after years of self-experimentation. What Lindsay elsewhere terms "the discipline of self-denial"-or "the comparatively small self-denial required to give up animal food" [22] (p. 43)-required a re-disciplining of the self, a struggle in which she formed herself into an ethical subject, squaring her theory with her practice. Lindsay and other nineteenth-century vegetarians thus used the act of self-fashioning and self-discipline to manifest a broader critique of society and the treatment of nonhuman animals. They undertook a politics of everyday life, or what Foucault calls "the politics of ourselves” [38] (p. 190).

I want to draw attention to the context of Lindsay's vegetarian narrative, the Women's Penny Paper, which was founded in 1888 as a newspaper oriented toward women readers [12] (p. 100). Feminist newspapers and journals of the fin de siècle helped women forge new political identities and communities. Thus, whereas ethical self-formation for the private Greek citizen was an individual relationship to the self, the feminist press allowed Lindsay's dietary self-fashioning to become part of a larger conversation and collective moment. The appearance of Lindsay's vegetarian confession in the Women's Penny Paper alongside other letters on suffrage, equal rights, marriage laws, rational dress, and social reform situated vegetarianism within a conversation on issues that concerned women. Lindsay's self-disclosure before the politically-minded audience of the Women's Penny Paper specifically focused on cultivating a model of autonomous female agency and subjectivity. She presented her own experimentation in diet, but also invited others to take on the experiment: "[ $t]$ he fact is, every individual vegetarian is an independent experiment in physiology” [39] (p. 210). Vegetarians, Lindsay suggested, were not passive consumers of food, science, or text, but were themselves active and independent producers of knowledge on physiology. Lindsay and other feminist vegetarians saw themselves as the managers of their own health, who together constituted a collective body of evidence to challenge medical orthodoxy on animal protein. Furthermore, by conducting their lives as independent experiments, vegetarians not only contributed to the vegetarian movement, but also used vegetarian dietetics to transform themselves and, as Foucault might say, shape their lives into an oeuvre [32]. 
To develop this argument on vegetarianism as an exploratory practice of the self, I will turn toward one particular message within the Vegetarian Messenger. In the issues I have examined from the early 1890s, Lindsay, in addition to her position as editor, contributed a column appropriately titled, "New Foods," in which she took on the role of a vegetarian pastor, guiding readers to their food and salvation. She displayed her fluency with scientific terminology not to advocate vegetarian principles, but to make the dietary experiment practicable for her readers. Lindsay's column did not address outsiders who needed convincing, but those who, while partially convinced of vegetarianism's ethical demands, still needed help with the practice. Writing in date-stamped periodical [17], Lindsay addressed herself to the present and to those struggling with the daily routine of living and cooking as a vegetarian. Each month, in the same familiar tone, she introduced her readers to a list of the latest "New Foods" on the market. Articles that we now recognize as common staples of grocery stores, such as cashews, dried coconut, yams, Italian rice, bananas, limes, and pine nuts, reflected the expansion and globalization of the trade in food, but it also helped push the vegetarian diet beyond the monotony of potatoes and bread. As she lamented to her readers, "bread and potatoes are often the only things a Vegetarian can get at a non-Vegetarian table” [40] (p. 12), and thus she liked to "experiment” with "a change at home" (p. 13), trying out different foods "to take the place of bread as the chief constituent of a meal” (p. 13). Her column, like the consumer society it hoped to transform, emphasized variety and novelty, while her dietary experiments opened up a channel of communication between the private space of her home and that of her readers. She shared her personal experiences with new products, but she also invited readers to experiment in their kitchens and report back on their gastronomic successes, turning readers into contributors. She addressed, but also helped call into being, a community of readers and eaters.

\section{New Foods, New Women}

Food in the Victorian period (its purchasing, preparation, and consumption) was intertwined with definitions of femininity, and the vegetarian interrogation of domestic practices inevitably collided with discussions of “the woman question" and women's role in public life. Because vegetarian food reform infringed upon the territory traditionally ruled by women (the management of food, health, and the home), and because it appealed to traditionally "feminine" attributes (sympathy and compassion), it demanded attention from women, but it also re-worked these traditional tropes into the exploration of new gender formations and material practices. In doing so, it opened up debate on the political and public role of women, a debate that was carried on not just within the Vegetarian Messenger. The Woman's Herald, the Woman's Signal, Shafts, Woman's Life, the Woman's Voice, and the Woman's Penny Paper all carried features and correspondence on vegetarianism and vegetarian recipes. The autonomous and physiological experimentation advocated by Lindsay provided the impetus and rationale to re-evaluate the identities, practices, and gendered scripts that were so closely tied to food preparation and consumption. The "woman question" and "vegetarian question" impacted upon one another.

Beatrice Lindsay's adherence to vegetarianism derived from humanitarian motives rather than motives of self-interest (hygiene, health, or economy), but in the 1890s she perceived what she described as "a great change in matters relating to cookery" [41] (p. 321), a change that demanded a 
corresponding shift in vegetarian tactics and propaganda from polemical arguments toward the art of cookery. Vegetarians now had some common ground with their enemies, and the world was much more hospitable to vegetarians. The "solid joint" of previous decades, which had formed the centerpiece of mid-Victorian tables and social rituals, was, Lindsay claimed, "no longer a necessity at respectable dinner parties" [41] (p. 321), and "when you were invited to dinner, there was even a chance of getting something Vegetarian to eat” [41] (p. 321). Even the 1888 edition of Mrs. Beeton's Book of Household Management [42] contained a new chapter on vegetarian recipes, while in 1891 the popular publisher, Cassell, released Cassell's Vegetarian Cookery [43]. Reflecting on the history of the vegetarian movement, Lindsay argued that, while much had been achieved "in the battering ram fashion" of outspoken advocacy, now was the time for "the silent process of growth" [27] (p. 415). Proceeding in the spirit of friendship and moderation, rather than the "advocacy of extreme doctrines," would, Lindsay believed, gain greater favour with public opinion. In the 1890s, the "world [was] acquainted with the principles and practice of Vegetarianism," and "therefore Vegetarians may now tone down their style of talking, for we have not now, as was the case forty years ago, to dispute with enemies but with half-convinced friends, who would like to become vegetarian, only they think it so difficult” (p. 415). While many of "our half-won converts” were now receptive to vegetarian ideas, they lacked the practical knowledge to conduct it in the home. Hence, Lindsay argued that "[g]ood cookery is the best means for popularizing the Vegetarian diet. It is all very well to give 24 reasons for being a Vegetarian, but people will not adopt the better diet if they are not taught how to cook a Vegetarian meal properly” [41] (p. 321). "24 Reasons for a Vegetarian Diet” was indeed the title of a halfpenny pamphlet sold by the Vegetarian Society. Providing a litany of arguments based on chemistry, natural history, economics, physiology, anatomy, and hygiene had become a well-trodden genre within vegetarian advocacy, but Lindsay recognized that reasons for being a vegetarian would not teach anyone how to live as a vegetarian. Now was not the time for combative arguments, but pastoral guidance. Rather than assert the moral reasons behind her diet, Lindsay's emphasis on good cookery addressed the quiet, unheralded, and slow transmission of material and culture practices. Her column on "New Foods" mobilized the periodical as a collaborative space for the collective exploration of vegetarian habits. In this way, she invested her readers in the construction of the practice of vegetarianism, and brought together a flock of vegetarians.

The title of Beatrice Lindsay's column condenses the objectives of the Vegetarian Society into a succinct statement: new foods. Vegetarian advocates aimed to introduce new foods into daily routines. For the middle and upper classes - that is, for those who could afford meat regularly — conversion to vegetarianism required that one eat differently, relinquishing customary tastes in favour of a dietary regime that was most commonly associated with poverty or eccentricity. From its foundation in 1847, the Vegetarian Society emphasized the benefits of abstinence and simplicity in diet, but the advertising and the commodity culture of the late-nineteenth century were driven by "the quest for superfluous variety” [44] (p. 26). We may, therefore, read the emphasis on novelty in "New Foods" as an attempt to compete with and adapt to the late-Victorian consumer culture. The Vegetarian Society published works of vegetarian cookery that appealed to the domestic ideal, but I focus here not on the way in which women were instructed in vegetarianism, but the way in which they collectively invented it through experimentation. In particular, I address the way in which the form of the periodical, rather 
than simply its content, popularized vegetarianism because, as a genre, the periodical specialized in integrating new ideas and unfamiliar content within regular, consumable instalments.

James Mussel argues that, much like scientific experiments, the print forms of the press were designed to assimilate, organize, and make sense of what was new. In Mussell's phrasing, periodicals "cohered knowledge" [45]: they transformed the unfamiliar into the familiar, and gave meaning to the flux of the modern world by organizing it according to a set of repeated generic conventions. The defining characteristic of the periodical is, therefore, a constant negotiation between novelty and repetition, change and continuity, difference and sameness. As Margaret Beetham argues, each number is different, but it still represents the same periodical [17]. The repetition of recurrent formal features such as the masthead, layout, price, paper quality, and typography allowed periodicals to forge a stable, familiar relationship with readers across time. Formal layout, however, not only produced and reproduced the publication's identity; it also provided the framework through which readers understood novel, changing content. The repetition of genres in the press mitigated the force of the unknown by placing it within categories that readers were already familiar with. Beatrice Lindsay and the Vegetarian Society not only had to create, through the repetition of form, the identity of their journal; rather, they also had to familiarize readers with the novel content of their diet, new vegetarian foods. Vegetarian periodicals and vegetarian practice had the same objective: to introduce new content within recurrent and established forms. The periodicity of serial publication also provided a monthly rhythm around which vegetarians could anchor the smaller cycles of daily consumption and practice.

The great changes in late-Victorian cookery described by Lindsay were partly made possible by the appearance of newly imported goods and commodities, which flooded the marketplace and adorned the covers of the Vegetarian Messenger. The practice of vegetarianism entailed navigating and making use of this growing consumer culture for one's own distinct humanitarian objectives. If we glance at the front and back cover of the Vegetarian Messenger from April 1898 (Figure 1), we can quickly identify several differences between the austere, male-dominated vegetarian world of 1849 and the vegetarian commodity culture of the 1890s. The Vegetarian Messenger is now personified as an angelic female figure who trumpets the vegetable gospel to the world, a neoclassical image that visually associates the Vegetarian Messenger with the iconography of the feminist journal Shafts [46], but also with the "Grecian figures” of popular advertising at the fin de siècle [44]. Notably, Cadbury's Cocoa occupies the position above the masthead, suggesting that vegetarianism was becoming identified with brand name commodities. Before readers could reach the first article listed in the table of contents, they had to flip through nine more pages of advertisements that specifically addressed a niche market of vegetarian consumers. We encounter Fromm's Extract, Nucoline Pure Vegetable Butter, Falona Health Food, Pure Palm Oil Soaps, and other products that were, as they often claimed, made by and for vegetarians. A world of producers and vendors arose to satisfy, sustain, and please the vegetarian movement and make possible a vegetarian culture. Gendered advertisements for products such as knitting machines, the Queen's Pudding Boiler, sanitary vegetable oil soaps, and health foods provide us with a potential resource for reconstructing the magazine’s shifting readership.

The gradual decline of the mid-century liberal model of the press — which published parliamentary speeches, leading articles of political commentary, and addressed an audience primarily of men-was no great loss for the Vegetarian Society, the members of which recognized that they could not win coverts to their way of life only through the ideal of rational debate in the public sphere. The commodification 
of the press and the expansion of advertising for household goods in the second half of the nineteenth century provided the Vegetarian Society with a wider array of extra-parliamentary avenues for promoting vegetarianism and reaching out to new audiences. The audience that many advertisers wanted to reach, and for which newspapers supposedly sacrificed their political role, was one composed of middleclass women, whom advertisers perceived as "the agents of material acquisition" [44] (p. 9). As Margaret Beetham notes, the "commercialization” and "de-politicization” of journalism were held to be synonymous with its "feminization": the New Journalism of the late nineteenth century appealed to feeling, sensation, and domestic issues rather than the public world of politics [17] (pp. 119-122). One can regard this appeal to women readers as “depoliticization,” but, as I want to suggest, the Vegetarian Messenger, by borrowing the styles and strategies of commercial journalism, engaged in another form of politics, the politics of everyday life. The Vegetarian Society did not work through conventional parliamentary means, but through the construction of cultural practices and daily routines. In constructing a vegetarian way of life, the peripheral pages of advertisements for vegetarian commodities were as important as the more overtly propagandistic and argumentative content of the journal. Advocacy and advertising were complementary rather than antithetical in the Vegetarian Society's attempts at social reform.

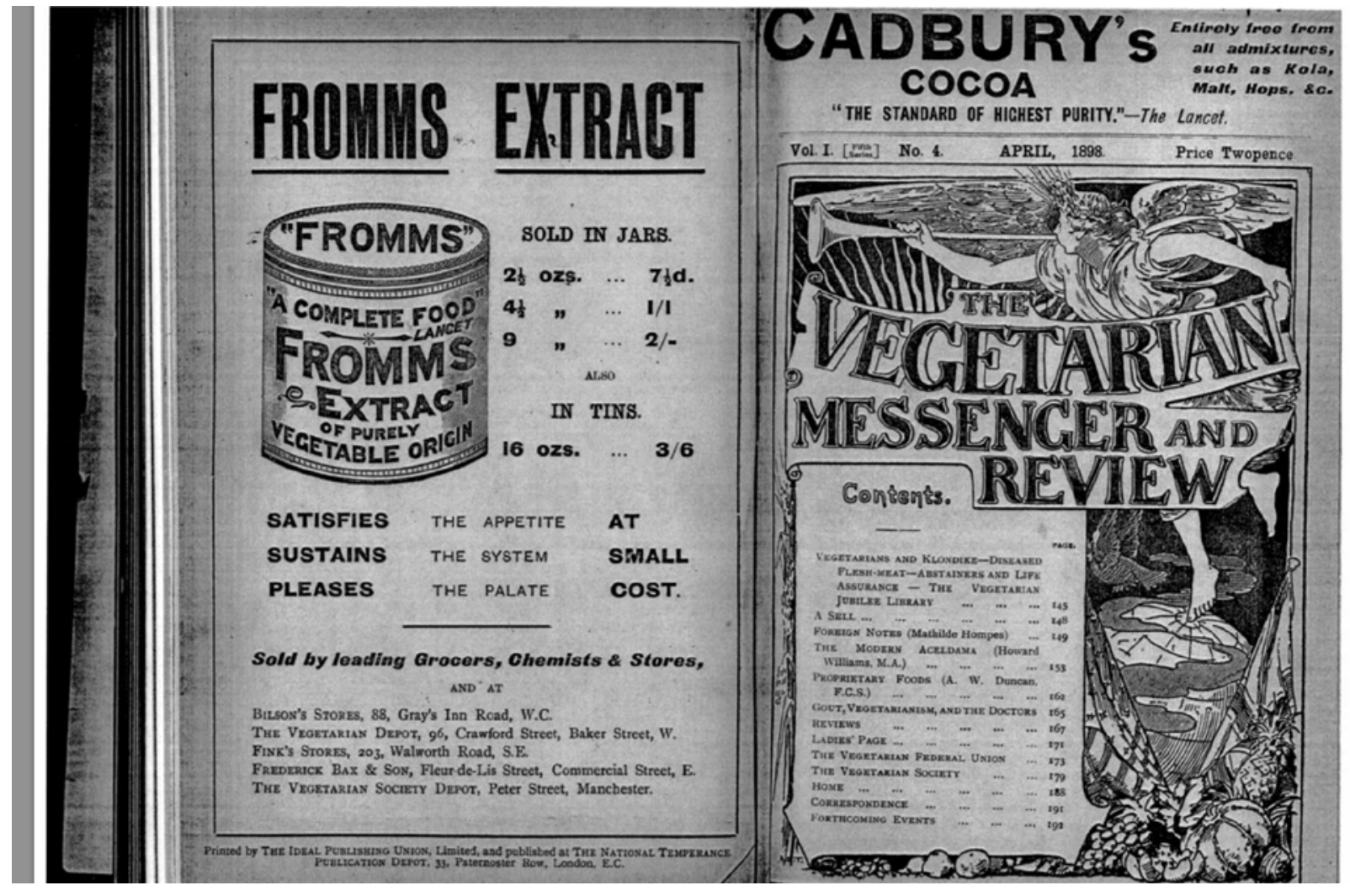

Figure 1. The front and back cover of the Vegetarian Messenger from April 1898 reveals the commercialization of vegetarianism.

As Laurel Brake laments, well-intentioned attempts to preserve nineteenth-century periodicals in bound volumes often discard their title pages and surrounding advertisements, and this excision redefines the meaning of the text [10] (pp. 27-29). The practice of reissuing periodicals in bound volumes presents them in the timeless form of a book, and it occludes essential features of periodicals: 
namely, their serialization, close connection to time, and rootedness in material, popular culture. The Vegetarian Messenger was not a profit-making enterprise. Nonetheless, advisements played an integral, rather than a peripheral, role in the periodical. Far from being "ephemeral," advertisements for vegetarian products represented one of the most permanent aspects of the issues I have seen from the 1880s and 1890s. Advertising contracts were entered into on a yearly basis, and thus, while the articles and other content changed every month, the advertising remained the same throughout the year. Repeated each month, the images of Nucoline vegetable butter, Nuttose health food, Dr. Nichols' Food of Health, and Vejos vegetable extract composed a recurrent and familiar feature of the periodical's physical identity and appearance, and were thus central to the reader's experience. Advertisements also formed an essential part of periodical's objective: to constitute a community of vegetarians. Under Beatrice Lindsay's editorship, the journal created a dynamic interrelationship among its recreational, social, commercial, and more overtly humanitarian and propagandistic functions. Pleasure, consumption, identity formation, and ethics all came together in the practice and advocacy of vegetarianism.

\section{Serial Eating}

In January 1891, Lindsay greeted readers of her "New Foods" column with the "welcome news" that Mr. W.S. Manning of London had "started an agency for fruit, nuts, and other useful vegetarian, (or V.E.M.) foods” ${ }^{4}$ [40] (p. 12). New foods were newsworthy items for vegetarians, and each month Lindsay kept her readers informed on "the novelties that Mr. Manning is introducing” [47] (p. 62). Mr. Manning was himself a vegetarian advocate, who became active in the 1880s with the London Food Reform Society, organizing cookery demonstrations and educational dinners. In the Vegetarian Messenger, his list of "Fruit and Nuts, Fresh or Dried-Foreign or Home Grown-Wholesale or Retail” were called for in recipes sections, recommended in Lindsay's column, and displayed in its advertising pages, thus creating porous borders between the journal's paratextual advertisements and internal content, or between its commercial and propagandistic functions. For instance, Lindsay recommended Mr. Manning's chestnut flour "for use in soups" [48] (p. 260), and then referred her readers to "recipes contributed by Madame Risos to the June Vegetarian Messenger" (p. 261). Hence, she used the intertextuality and seriality of the periodical to bring together a community of women who could exchange recipes, ingredients, and ideas. Vegetarian substitution required not only replacing meat with vegetables, but also creating an alternative social and economic order that could support a vegetarian way of life. The collaborative relationship between Lindsay and Manning demonstrates how vegetarians worked to intervene in production and consumption, or in the economic system that made different foods available, and in the everyday uses of foods. Lindsay played the role

4 V.E.M. stands for vegetables, eggs, milk. Francis Newman, president of the Vegetarian Society from 1873-1884, developed this phrase, the V.E.M. diet, in order to present the wide range of foods available to vegetarians. The term "vegetarian," he argued, misleadingly implied that members of the Vegetarian Society subsisted solely on vegetables. While some nineteenth vegetarians practiced a strict vegetarian diet, which we would now call a vegan diet, most admitted the use of dairy and eggs. Internal debates raged over the proper practice and terminology of vegetarianism, and Lindsay’s use of both terms, “vegetarian (or V.E.M.) foods,” suggests she may have been attempting to avoid controversy and appeal to a broad audience of both the uncompromising ascetics and the more liberal diet reformers. 
of mediator within this network of consumers and producers; she tried different products and identified those commodities that bore the most applicability to her readers. She was, we might suggest, a food critic, and yet, as I want to say, her role was productive rather than simply descriptive. She received food samples from distributors such as Mr. Manning, and each month in her column on "New Foods" she related her opinions of these vegetarian specialities, telling readers the costs, quantities, and potential uses of the articles sold by Mr. Manning's company:

I may name the following items in Mr. Manning's list: White Grapes (French), at 6d. per lb.; West Indian Limes, at 6s. per doz.; Tasmanian apples, 4d. per lb.; Barbadoes tamarinds, 3d. per lb.; and dried-pine apple, which, to my taste, is much preferable to the favourite crystallised kinds on account of containing only its natural sugar [48] (p. 259).

Each newly imported product on the list was accompanied by a description of its price, taste, and potential use in vegetarian households. Lindsay's interjection of her preferences ("to my taste") added a level of personal intimacy to what would otherwise be a standard price list. This self-disclosure allowed her to unfold before her readers an authorial persona whom they could learn to trust. She further familiarized readers with the appearances and flavours of exotic products by placing them within recognizable culinary and taxonomic classifications. For instance, readers learned that yams “are very like potatoes only with a slightly sweet flavour" [47] (p. 62). And, like potatoes, yams are also easily boiled into a floury substance, but "they are not like the potato, a tuber, but a rhizome; that is to say, they are not round offshoots born on the root, but are enlarged parts of the root itself” (p. 62). Lindsay used the growing cultural authority of science not to abstract food into its chemical properties, but to make unknown foods tangible and concrete. She related the foreign to the domestic; yams fell within the same taxonomic family as "the beautiful bindweed of our English lanes" (p. 62). Readers also learned that cashew nuts were the product of a tree in the American tropics, the fruit of which was "exactly comparable in botanical structure to the strawberry" (p. 61). In taste they stood between the almond and pistachio. This epistemological work of classification was necessary to enable vegetarian activity: people tend not to eat something if they do not first know what it is. Lindsay made new vegetarian foods comprehensible and, hence, consumable for her readers.

One the principal tropes Lindsay used to reconcile new foods with her readers' already-existing culinary knowledge was thus analogy. However, the periodical itself also provided a cultural framework for integrating variety and difference into the lives of readers. Lindsay's columns emphasized novelty, change, and variation from the monotonous routine of bread and potatoes, but she also drew attention to the serial continuity and repetition of her medium. For instance, she concluded her January 1891 column by noting, "The above list of foods is well worth the attention of those who are not yet familiar with the articles I have named, and I shall hope to introduce some others to the notice of my readers next month" [40] (p. 13). The work of satisfying the vegetarian body was an open-ended process, an exploration that would continue with next month's issue. Mr. Manning was, readers learned, "still adding to the variety of his selection of fruits and other Vegetarian foods" [48] (p. 259). There would always be a new food to eat just as there would always be a new issue to read. Lindsay thus closely intertwined reading and eating practices, and balanced novelty against formal repetition. She introduced dietary changes and new foods to her readers, but did so within the familiar and repetitive form of the monthly magazine. Through her use of established taxonomies and conventional 
print forms, she gradually gave shape and meaning to the undefined practice of vegetarianism. Notably, subscribers received their vegetarian journals and their vegetarian foods in the same way: through the post. Manning's agency, Lindsay claimed, enabled vegetarians living in the country or away from market districts to order fresh or dried fruit at wholesale prices, making fruit "a staple article of food, instead of an expensive luxury, as it used to be a few years ago" [48] (p. 259). Hence, isolated vegetarians could anticipate receiving their monthly magazine and their delivery of sultana raisins, West Indian limes, and dried pineapple in the same manner, making vegetarian texts and foods staples of the everyday.

Much like the periodical, the practice of vegetarian cookery itself involved mixing familiarity with novelty. It was process of adapting new content to fit within traditional forms in order to meet the needs of the present. Lindsay frequently represented it as a struggle between inherited social conventions and tactical innovation. In the January 1891 issue, she drew her readers' attention to "a very satisfactory sample of nut meal” that she had “received from Mr. C Stamper, of Didsbury” [40] (p. 10). Made from ground hazel nuts, this nut meal could be used in cakes, as one would normally use ground almonds, but Lindsay claimed, "what is more important, it completely solves the problem of what to use as a strictly vegetarian butter" (p. 10). Lindsay's previous attempts to substitute for butter had all ended in failure for different reasons. Following the "recommendation of writers in the old Dietetic Reformer" (p. 11), she had tried "mashing pulse with oil," but this admixture fell short of the mark because it contained too much "starch," thus rendering it "entirely different in food value from butter" (p. 11). ${ }^{5}$ In addition to mashing lentils and other pulses, Lindsay had also experimented with olive oil, but, as she lamented, it was “too 'messy,' owing to its liquid form” (p. 10). However, olive oil stirred up with the Mr. C. Stamper's nut meal could be formed into a "paste such as can be spread with a knife" (p. 10). We see here, then, one of the small triumphs that made up the progress of vegetarianism. The recipes and recommendations of "writers in the old Dietetic Reformer" had been surpassed, and Lindsay had arrived at an adequate equivalent for butter, which she described to her readers in both practical and scientific terms, developing a popular science of vegetarianism: "The oily substance of the nut, distributed in its natural cells, and accompanied by a certain portion of mineral salts, does not present these objections [of previous attempts], and in these respects more nearly resembles ordinary butter" (p. 11). Lindsay "strongly recommend[ed] those who have experimented on vegetable substitutes for butter to try this mixture” (p. 11). It was, she said, particularly good with jam "in the way in which butter is much enjoyed by children, and usually forbidden by their parents" (p. 11). By identifying with the child's enjoyment rather than the parents' discipline, Lindsay seems more concerned with the pursuit of her own pleasure than with domestic duties to care for others. As Lindsay also indicates, finding a butter substitute was a "messy" problem, and her solution suggests bricolage, a creative way of using, manipulating, and enjoying the material world [49] (p. xxii).

5 For example, the November 1885 issue of the Dietetic Reformer and Vegetarian Messenger, the same issue in which first Lindsay appeared as the Editor of the Vegetarian Society, published a recipe for "Vegetarian Butter" contributed by a correspondent who signed his or her name simply as “C.H.R”: Vegetarian Butter-A cup of lentils steeped till soft, simmer for five minutes, pour out and stand till cold, then add a few fine bread crumbs, and a little grated cheese, pepper, and salt, and grated nutmeg, and put in pot. 
Vegetarianism required tactical and very tactile consumer practices, an ability to appropriate the goods of an expanding commodity culture, and materially re-shape these objects to fit one's own purposes.

Finding "a strictly vegetarian substitute for butter" was an everyday and seemingly trivial problem for vegetarians. Worrying about what to use for butter did not make front-page news, not even in the Vegetarian Messenger, which usually led with a summary of recent events, annual reports and speeches, or an appeal to the reader. Lindsay's columns appeared near the end of each issue, with the correspondence and recipe pages. They brought together the ephemera of material culture with social reform. Her admixture of hazel nuts did not directly address social progress or the moral status of animals, but it allowed her to reconcile her humanitarian principles with the established conventions of the table. Her experiments with nut-butter reveal for us the importance of what Michael de Certeau terms the activity of "making do" [49] (p. 35) in the vegetarian movement and in the invention of vegetarianism. For too long, de Certeau argues, we have assumed that production ends with consumption, and we have thus neglected to study what consumers do with the things they buy, or make of the images, texts, and discourse they assimilate from popular culture-that is to say, we have failed to acknowledge the subtle ways in which consumers are also producers of meaning. Statistical studies, such as those carried out by Dr. Edward Smith and the British Association for the Advancement of Science on the English diet [50] (pp. 96-99), record "what is used, not the ways of using” [49] (p. 35). In The Practice of Everyday Life, De Certeau attempts to theorize the invisible, silent, and unrecognized "ways of using," which he describes as the "creative tricks of the 'weak' within the order established by the 'strong,' an art of putting one over on the adversary” (p. 40). Through a variety of "tactics," users appropriate cultural products according to their own rules and interests, thereby making daily rituals (cooking, eating, walking, reading) sites of contestation: "the tactics of consumption, the ingenious ways in which the weak make use of the strong, lend a political dimension to everyday practices” (p. xvvii).

Vegetarian cooking made consumption productive; it operated through the citation and imitation of the norm, but also created new uses for foods and products. Lindsay shaped hazel nuts into butter; she gave "messy" vegetarian food a solid form, but, by reproducing the texture, pleasure, and function of butter, she also created something new. Vegetarian cooking and eating relied on imitation as well as artistic trickery and parody. It entailed a negotiation between novelty and familiarity, between modern ethical convictions and past culinary traditions. How could a vegetarian survive the temptations of the Christmas season? Lindsay had an answer; she recommended pine nuts, another one of the "novelties introduced by Mr. Manning” [40] (p. 12), as "the best substitute for suet in the Christmas pudding” (p. 12). The pine nuts and other "novelties” recommended by Lindsay were available for anyone to purchase, but these articles developed specific uses and meanings within vegetarian circles and social rituals. Using pine nuts instead of suet allowed Lindsay and her readers to eat within the customs of society, but according to their humane rules and principles. They operated within the economic and culinary system that they aimed to subvert. Tactical vegetarian eating struck a balance between traditional forms, such as the iconic shape of Christmas pudding, and new commodities. It reproduced established dishes, but, through this repetition, it aimed to make possible a new understanding of the appetites and their attendant pleasures. The vegetarian parody aimed not simply to imitate the meaty original, but also to denaturalize and displace it, revealing its fleshy essence to be non-essential and substitutable. 
Lindsay's monthly column was thus oriented toward enabling new vegetarians to survive in a fleshy world and partake in the experiences of modern life. She reveals for us the material practices and small innovations that made possible vegetarian ways of living. Nineteenth-century vegetarians were a peripheral minority, a group of eccentric consumers who lived on the margins of an omnivorous culture, but when discussing the tactical ruses of "the weak" over "the strong” we must remember that their "ways of operating" and "making do" were carried out in name of another marginal and increasingly invisible group: nonhuman animals. In the three columns that I have surveyed, Lindsay mentions the lives of animals only once. She concludes her September 1891 list of new foods by recommending Mr. Manning's excellent coconut oil, at 6d. per pound, for the purpose of frying. "It is very satisfactory," she claims, "and should be tried by all those wish to minimise the use of animal products" [48] (p. 260). She leaves it open for readers to determine why they might "wish to minimize the use of animal products" (p. 260), allowing them to construct their own understanding of vegetarianism. This work of minimization draws attention to the central irony in Lindsay's column: she used the resources of an expanding consumer society-its commercial media, advertising, and desire for endless variety-in the name of minimization, contradicting and critiquing the ethos of consumerism, the desire for more. However, the substitution of coconut oil for animal fat was not felt to be a diminishment or sacrifice of pleasure, but was carried out in the pursuit of other pleasures. Morality and enjoyment were not at odds in Lindsay's articulation of vegetarianism. Rather, the ethical consumer was in conflict with her surrounding world. Daily existence was figured as both a scientific experiment and a battlefield in which the vegetarian struggled to use the system for her own ends. A provision of bananas, Lindsay advised her readers, would protect the conscientious eater against "a siege, or against—what is almost as bad-a railway journey in the provinces” where only ham sandwiches were served [47] (p. 63). New foods were thus part of the tactical battle of "the weak" over "the strong". While situating them within taxonomic categories, Lindsay also positioned foods in relation to concrete situations, such as a railway journey, a day's hike, or Christmas dinner. Her column, "New Foods," suggests that food can be an agent, rather than effect, of social and cultural change, altering the way we behave, act, live, and create meaning. The introduction of new foods into the diets of consumers brings more than dietary variety, but makes possible more humane ways of living, and Lindsay presents the exploration and informed use of new foods as a way to operate within and struggle against the existing social order. The invention of everyday vegetarianism was an exploratory, messy, and collaborative process, and Lindsay used the periodical press to give form and legibility to this “invisible” practice.

Notably, Lindsay did not address her readers as the "mothers, wives, and daughters" of England, appealing to the ideal of the English domestic woman. Rather, from her tastes and recommendations we can reconstruct a brief glimpse of her life and see how new foods made possible the new lifestyles. Whereas much Victorian household literature circumscribed women within the home, presenting an economic system for maintaining the respectability of the family, Lindsay focused on her own personal tastes and appetites, and she seemed to have been interested in foods that enabled mobility, taking her outside of the home. For instance, she introduces dried green beans, one of "the Vegetarian specialties" available from Messrs. Brett and Co., by drawing on readers' shared experience of urban vegetarian restaurants rather than their experience in the kitchen: "Everybody who has visited the chief Vegetarian restaurants knows the Austrian bean soup” [40] (p. 11). We might reasonably infer from 
this comment that she and her readers were the very type of people who enjoyed dining in public and visiting the chief vegetarian restaurants of London and Manchester. Further, when Lindsay recommends bananas with coffee as "an excellent lunch for purposes of 'hard reading'” [47] (p. 63), she draws our attention to her "hard"-perhaps connoting masculine-intellectual ambitions rather than her domestic duties. Or when she suggests dried fruit and shelled hazel nuts as a "provision for a journey or a day’s walk” (p. 62), we get the impression that Miss Beatrice Lindsay is cooking for one, or perhaps not even cooking. She appeals to readers' individual tastes rather than domestic duties, addressing those who visit restaurants and snack on nuts rather than bake homemade bread. At the time, the very idea of "snacking" seemed to suit the habits of modern vegetarians, many of whom advocated eating frequently but lightly on raw, "natural" foods. Some of the items Lindsay recommended were oriented toward quick meals rather than home cooking, reflecting the dietary and social changes of the nineteenth century. She begins one column by introducing readers to "Rizine", a packaged and processed form of rice, which, because it had been pre-cooked by steam, could "be prepared very quickly. [...] This ought to render it very useful in households where there is little time for cooking” [47] (p. 61).

As a citational and reiterative practice, vegetarianism imitated the routinized rules of domestic cookery, but, for its success, it also required its own daily repetition and imitation, and thus vegetarian cookery was itself subject to the forces of difference within iteration. Readers did not simply read vegetarian periodicals or cookery books; they also tested them out, put them into use, and incorporated vegetarianism their own practice. Agency, as Butler argues, is found not in the refusal of repetitive practices, but "within the possibility of a variation on that repetition" [51] (p. 198). Beatrice Lindsay encouraged her readers to take up, cite, repeat, and appropriate the practice of vegetarianism, forging their own agency through the repetitive of acts of cooking and eating. She created agents and practitioners of vegetarianism. The Vegetarian Society had, of course, published works of cookery well before Lindsay became involved in the dietary reform movement. Her tactical innovation lay in the fact that she took advantage of the participatory, open-ended framework of the periodical, inviting readers to become the co-authors of vegetarianism. Lindsay, rather than present readers with "the complete vegetarian cookery", emphasized incompletion, presenting the vegetarian lifestyle as a personal, ongoing process of experimentation rather than a rigid routine of household management. Instead of telling readers what to eat and how to prepare it, she involved them in a dialogue.

For instance, in her column from September 1891, Lindsay drew her readers' attention to “a story going the round of the papers lately of a lady who is trying the culture of the common plant called groundsel as a profitable crop" [48] (p. 259). New foods, apparently, were news not just in the Vegetarian Messenger, but throughout “the papers”. Lindsay had previously considered the plant "a very tiresome weed", but it now seemed as though it might be "eatable as salad" or boiled in the way one cooked spinach. Having never tried it herself, Lindsay asked her readers to investigate: "Will any of our friends give it a trial, and report to me regarding their success?” (p. 259). Lindsay may have addressed readers through the medium of print, but she preserved the oral and communal culture of cooking, eating, and talking: she asked her readers to explore the world with their tongues, to eat new things and then report back on their experiences. Lindsay did not diffuse abstract information on the nutrition or dietetics of the Vegetarian System; instead, she cultivated tastes and ways of "making use", creating embodied knowledge of the world. Not all of the products she recommended were 
imported; some, like groundsel, were native plants: “Another common weed I have always thought of as a possible subject of experiment-the chickweed” (p. 259). The vegetarian diet, as Lindsay presented it, was a continual experiment with one's local environment and with oneself. Readers, as I want to stress, were central to this process. Lindsay drew upon readers' experiences to constitute her columns, unifying experiments in eating with monthly periodical reading:

I shall be glad if any of my readers who meet with new or especially excellent food, will send me a small sample, or information as to where the foods in question may be obtained. It will be, of course, understood that I have tried all the different articles which I introduce to my readers; but probably individual tastes differ, and some may not like everything I recommend, while I, on the contrary, may dislike other articles that they might think worthy of notice. But since individual tastes differ, it is always an advantage to become acquainted with as many different varieties of food as possible [47] (p. 63).

Removing the professional anonymity of the editorial voice, Lindsay here creates a relationship of personal trust and intimacy with readers: she assures them that every article she recommends she has eaten herself, revealing a glimpse into her private life. Tastes differ, as Lindsay recognized, and rather than seek to dictate the diets of readers, she created a dialogue that, because of the serial form of the periodical, could carry on over several issues, keeping readers interested and engaged in on-going vegetarian experiments. The ability "to become acquainted with as many different varieties of food as possible” was a privilege and product of the late-Victorian consumer society. But, as I am suggesting, Lindsay used the exploration of individual tastes and the consumerist desire for novelty to realize her own moral ends. Moving away from the asceticism of earlier vegetarians, Lindsay and her readers constructed a new understanding of what it meant to be and live as a vegetarian, constituting what Lauren Berlant and Barbara Green discuss as "an intimate public sphere” [52,53], a community of strangers mediated by common texts and the consumption of similar things. Together they transformed the negative critique of flesh consumption into a positive technology of self-care, and used themselves as the testing ground to expose the epistemological, ontological, and moral limitations of their time.

\section{Conclusions}

If, by way of conclusion, we read Lindsay's columns on vegetarian experimentation in relation to the correspondence published in the same issues of the Vegetarian Messenger, we can see how the periodical, rather than simply instruct its readers in vegetarianism, provided the infrastructure for readers, writers, and editors of both genders and from across the country to share their practical experiences, daily meal plans, and favourite recipes. As Barbara Green argues in relation to feminist periodicals, letters columns "provided room for a discourse of self-disclosure that enabled the production of new subjectivities" [53] (p. 464). The autobiographical discourse in the pages of vegetarian periodicals brought together a community that was based upon the exchange and communion of food. Self-disclosure in letters columns allowed individuals to publicize their private trials with the diet and test out the identity of "the vegetarian." For instance, joining an ongoing conversation, Mrs. Harrison wrote in the January 1891 issue, "I have the pleasure of adding my testimony with that of the others, to the good of Vegetarianism [...] I am willing to correspond with, or 
send recipes, or visit anyone so desiring it” [54] (p. 21). Similarly, Hanah Thorton, of Chestnut Cottage, Great Haughton, St. Neots, wrote in to "beg to add my testimony to that of Mrs. Ida Devade, 6, Fawcitt Terrace, Southsea, that I have proved Vegetarianism the most healthful way of living” [55] (p. 26). Correspondence collapsed distances, creating the impression of a direct link between the addresses of isolated vegetarians. By accumulating their testimony together, and by sharing their recipes and personal regimens, readers such as Hanah Thorton and Ida Devade lent support to each other and created a community. Crucially, the publication of their letters also gave them the opportunity to see their own dietetic experiments reflected back at them in the print, affirming their personal agency and providing a model for others to take up and follow: as Hanah Thorton claims, "I have proved Vegetarianism", emphasizing her own agency and individual contribution to the cause as well as publicly declaring her adherence to vegetarianism. The periodical format, which invited the engagement and participation of its readers, helped to create this forum in which readers, by contributing to the content of the vegetarian periodical, were also contributing to the creation of themselves and the meaning of vegetarianism. Their narratives of converting to a fleshless diet were acts of self-creation that not only gave substance to the new subjectivity offered in journal's title, the Vegetarian, but also made self-care a political exercise. The participatory nature of the periodical was critical to the formation of vegetarian subjects. By proving vegetarianism as the most healthful way of living, individuals like Hanah Thorton also bound themselves to this way of living and the vegetarian identity. The discussion and dissemination of vegetarianism in the nineteenth century worked through the proliferation of agency rather than the disciplining of desires.

\section{Acknowledgments}

I would like to thank the Vegetarian Society for allowing me to conduct research in their archives, Susan Furmage for her help with Beatrice Lindsay, Chloe Taylor for her editorial advice, and my reviewers for their suggestions.

\section{Conflicts of Interests}

The author declares no conflict of interest.

\section{References}

1. Anonymous. General. Diet. Ref. Veg. Mess. 1883, 9, 200.

2. Anonymous. Executive committee. Diet. Ref. Veg. Mess. 1885, 12, 256.

3. Lindsay, B. On the Avian Sternum. Proc. Zool. Soc. Lond. 1885, 53, 684-716.

4. Lindsay, B. An Introduction to the Study of Zoology; Swan Sonnenschein \& Co: London: UK, 1895.

5. Lindsay, B. The Story of Animal Life; George Newness Ltd.: London, UK, 1902.

6. De Certeau, M.; Luce, G.; Pierre, M. The Practice of Everyday Life, Volume Two: Living and Cooking; Timothy, J.T., Ed.; University of Minnesota Press: Minneapolis, MN, USA, 1998.

7. Singer, P. Preface. In Animals’ Rights Considered in Relation to Social Progress; The Society for Animal Rights: Clarks Summit, PA, USA, 1980. 
8. Turner, M. Periodical Time in the Nineteenth Century. Media History 2002, 8, 183-196.

9. Mussell, J. Nineteenth Century Press in the Digital Age; Palgrave: Basingstoke, UK, 2012.

10. Brake, L. Print in Transition: Studies in Media and Book History; Palgrave Macmillan: Basingstoke, UK, 2001.

11. Lee, A.J. The Origins of the Popular Press in England: 1855-1914; Rowman and Littlefield: London, UK, 1976.

12. Tusan, M. Making the News: Gender and Journalism in Modern Britain; University of Illinois Press: Chicago, IL, USA, 2005.

13. Perren, R. Taste, Trade and Technology: The Development of the International Meat Industry Since 1840; Ashgate Press: Aldershot, UK, 2006.

14. Showalter, E. Sexual Anarchy: Gender and Culture at the Fin de Siècle; Penguin: New York, NY, USA, 1990.

15. Elston, M.A. Women and Anti-Vivisection in Victorian England, 1870-1900; Nicolaas, A.R., Ed.; Croom Helm: London, UK, 1987; pp. 259-293.

16. Richards, T. The Commodity Culture of Victorian England: Advertising and Spectacle, 1851-1914; Stanford University Press: Stanford, CA, USA, 1990.

17. Beetham, M. A Magazine of Her Own: Domesticity and Desire in the Woman's Magazine, 1800-1914; Routledge: London, UK, 1996.

18. Butler, J. Bodies That Matter: On the Discursive Limits of Sex; Routledge: New York, NY, USA, 1993.

19. McLuhan, M. Understanding Media, 2nd ed.; Signet: New York, NY, USA, 1964.

20. Bruce, F.J. Helpful Hints to Vegetarians. Veg. Mess. 1893, 7, 87-94.

21. Lightman, B. The Popularization of Evolution and Victorian Culture. In Evolution and Victorian Culture; Lightman, B., Zon, B., Eds.; University of Cambridge Press: Cambridge, UK, 2014; pp. 286-311.

22. Lindsay, B. Vegetarianism and Higher Life. In Manchester Vegetarian Lectures: First Series; Axon, W., Ed.; The Vegetarian Society: Manchester, UK, 1888; pp. 42-47.

23. Lindsay, B. Man Not Carnivorous. In Manchester Vegetarian Lectures: First Series; Axon, W., Ed.; The Vegetarian Society: Manchester, UK, 1888; pp. 69-77.

24. Butler, J. Giving an Account of Oneself; Fordham University Press: New York, NY, USA, 2005.

25. Jenkins, S. Returning the Ethical and Political to Animal Studies. Hypatia 2012, 27, 504-510.

26. Derrida, J.; Roudinesco, E. For What Tomorrow... A Dialogue; Fort, J., Ed.; Stanford University Press: Stanford, CA, USA, 2004.

27. Anonymous. Annual Meeting of the Vegetarian Society. Veg. Mess. 1893, 7, 398-419.

28. Kingsford, A. Lecture on Some Aspect of the Vegetarian Question. Diet. Reform. Veg. Mess. 1875, 15, 4-6.

29. Bruce, F.J. Vegetarianism in the Household. Veg. Mess. 1891, 5, 350-358.

30. Gleadle, K. 'The Age of Physiological Reformers': Rethinking Gender and Domesticity in the Age of Reform. In Rethinking the Age of Reform; Burns, A., Innes, J., Eds.; Cambridge University Press: Cambridge, UK, 2003.

31. Taylor, C. Foucault and the Ethics of Eating. Foucault Stud. 2010, 9, 71-88. 
32. Foucault, M. The Use of Pleasure: The History of Sexuality Volume Two; Hurley, R., Trans.; Vintage Books: New York, NY, USA, 1990.

33. Foucault, M. The Subject and Power. Crit. Inq. 1982, 8, 777-795.

34. Foucault, M. Security, Territory, Population: Lectures at the College de France, 1977-1978; Senellart, M., Ed.; Burchell, G., Trans.; Picador: New York, NY, USA, 2007.

35. Hopwood, N.; Shaffer, S.; Secord, J. Seriality and Scientific Objects in the Nineteenth Century. History Sci. 2010, 48, 250-285.

36. Foucault, M. The History of Sexuality: An Introduction; Hurley, R., trans.; Vintage Books: New York, NY, USA, 1990.

37. Lindsay, B. A Vegetarian Letter. Women's Penny Paper 1889, 58, 67.

38. Foucault, M. The Politics of Truth; Semiotext: Los Angeles, CA, USA, 2007.

39. Lindsay, B. Vegetarianism. The Women's Penny Paper 1890, 70, 210-211.

40. Lindsay, B. New Foods. Veg. Mess. 1891, 5, 10-13.

41. Annual Meeting of the Vegetarian Society. Veg. Mess. 1891, 5, 317-326.

42. Beeton, I. The Book of Household Management, new ed.; Ward, Lock, and Co.: London, UK, 1888.

43. Payne, A.G. Cassell's Vegetarian Cookery; Cassell and Co.: London, UK, 1891.

44. Loeb, A. Consuming Angels: Advertising and Victorian Women; Oxford University Press: New York, NY, USA, 1994.

45. Mussell, J. Cohering Knowledge: Form, Genre, and Periodical Studies. Vic. Period. Rev. 2009, 42, 93-100.

46. Beaumont, M. Influential Force: Shafts and the Diffusion of Knowledge at the Fin de Siècle. Interdiscip. Stud. Long Ninet. Century 2006, 2, 1-19.

47. Lindsay, B. New Foods. Veg. Mess. 1891, 5, 61-63.

48. Lindsay, B. New Foods. Veg. Mess. 1981, 5, 259-260.

49. De Certeau, M. The Practice of Everyday Life; Rendall, S., Trans; University of California Press: Berkley, CA, USA, 1988.

50. Burnett, J. Plenty and Want: A Social History of Diet in England from 1815 to the Present Day; Nelson: London, UK, 1966.

51. Butler, J. Gender Trouble; Routledge: New York, NY, USA, 2006.

52. Berlant, L. The Female Complaint: The Unfinished Business of Sentimentality in American Culture; Duke University Press: Durham, NC, USA, 2008.

53. Green, B. Complaints of Everyday Life: Feminist Periodical Culture and Correspondence Columns in the Woman Worker, Women Folk, and the Freewoman. Modernism/Modernity 2012, 19, 461-485.

54. Harrison, M. Letters Read at the Annual Meeting. Veg. Mess. 1891, 5, 19-21.

55. Thorton, H. Testimony. Veg. Mess. 1891, 5, 26-27.

(C) 2015 by the author; licensee MDPI, Basel, Switzerland. This article is an open access article distributed under the terms and conditions of the Creative Commons Attribution license (http://creativecommons.org/licenses/by/4.0/). 